\title{
Presence and significance of Bacillus thuringiensis Cry proteins associated with the Andean weevil Premnotrypes vorax (Coleoptera: Curculionidae)
}

\author{
Silvio Alejandro López-Pazos ${ }^{1}$, John Wilson Martínez ${ }^{2}$, Adriana Ximena Castillo ${ }^{1} \&$ Jairo Alonso \\ Cerón Salamanca ${ }^{1}$ \\ 1. Instituto de Biotecnología, Universidad Nacional de Colombia, A.A 14-490, Santafé de Bogotá DC, Colombia; \\ salopezp@unal.edu.co; axcastillog@unal.edu.co,jacerons@unal.edu.co \\ 2. Grupo Manejo Biológico de Cultivos. Programa de Ingeniería Agronómica, Universidad Pedagógica y Tecnológica de \\ Colombia. Tunja.Colombia; wilsonmarti@yahoo.es
}

Received 15-X-2008. C Corrected 20-III-2009. Accepted 20-IV-2009.

\begin{abstract}
The Andean weevil Premnotrypes vorax represents an important cause of damage to Colombian potato crops. Due to the impact of this plague on the economy of the country, we searched for new alternatives for its biological control, based on the entomopathogenic bacteria Bacillus thuringiensis. A total of 300 $B$. thuringiensis strains obtained from potato plantations infested with $P$. vorax were analyzed through crystal morphology, SDS-PAGE, PCR and bioassays. We used site-directed mutagenesis to modify the Cry3Aa protein. Most of the $B$. thuringiensis isolates had a bipyramidal crystal morphology. SDS-PAGE analyses had seven strains groups with $\delta$-endotoxins from 35 to $135 \mathrm{kDa}$. The genes cry 2 and cry 1 were significantly more frequent in the P. vorax habitat (PCR analyses). Three mutant toxins, 1 (D354E), 2 (R345A, $\Delta$ Y350, $\Delta$ Y351), and 3 (Q482A, S484A, R485A), were analyzed to assess their activity against $P$. vorax larvae. Toxicity was low, or absent, against $P$. vorax for isolates, wild type cry $3 \mathrm{Aa}$ and cry $3 \mathrm{Aa}$ mutants. The genetic characterization of the collection provides opportunities for the selection of strains to be tested in bioassays against other insect pests of agricultural importance, and for designing Cry proteins with improved insecticidal toxicity. Rev. Biol. Trop. 57 (4): 1235-1243. Epub 2009 December 01.
\end{abstract}

Key words: native strain, Andean weevil, Cry3Aa protein, potato crop, site-directed mutagenesis.

It has been estimated that 9000 species of insect pests affect commercial crops in the world. Sustainable control of insects in agriculture is very important since it was estimated that chemical control cost 7500 million dollars (Arrieta \& Espinoza 2006). In addition, the use of synthetic insecticides is not recommended because of the long residual action and toxicity to a wide spectrum of organisms, including human (Song et al. 2008). Consequently, interest has developed in the use of alternative strategies for biological control, such as Bacillus thuringiensis (Bravo et al. 1998).

The entomopathogenic activity of Gram positive $B$. thuringiensis is mainly due to the synthesis of large quantities of insecticidal crystal proteins (ICPs), or $\delta$-endotoxins, during sporulation that can be distinguished as distinctively shaped crystals under electronic scanning microscopy (Kati et al. 2007). These inclusions are comprised of toxins known as Cry and Cyt proteins. Up to date, more than 300 toxins have been cloned, sequenced, and classified into 55 groups of Cry proteins and two groups of Cyt proteins based on the amino acid homology (Crickmore et al. 2008). Cry proteins have been used as biopesticide sprays on a significant scale for more than 50 years, and their safety has been demonstrated (Schnepf et al. 1998). Some of the ICP genes have 
been applied for bioengineered crop protection, resulting in transgenic crop plants with excellent insect protection (Song et al. 2008). The active spectra of ICPs includes larvae of Lepidoptera, Coleoptera, Diptera, Hymenoptera, Homoptera, Mallophaga and Orthoptera (López-Pazos \& Cerón 2007). B. thuringiensis strains are distributed worldwide in soil, stored products, insects, insect breeding environments, and the phylloplane (Mahalakshmi et al. 2005). It is still necessary to search for more strains and toxins, since a significant number of pests are not controlled with the available. It is also important to provide alternatives for insect resistance, especially with regard to the transgenic crops (Bravo et al. 1998).

The Andean potato weevil (or White Worm as named in Colombia) Premnotrypes vorax (Coleoptera: Curculionidae) is a major cause of damage to potato crops in the Andean regions of Colombia, affects $75 \%$ of cultivated area, and $10-90 \%$ of the potato harvest losses are due to this insect (Herrera 1997). The aim of this study was to analyze the effect of $B$. thuringiensis on the survival of $P$. vorax. Firstly, to characterize a $B$. thuringiensis native strain collection from $P$. vorax ecosystem, and secondly, to identify, through bioassays, the biological activity of $B$. thuringiensis native strains against Andean potato weevil. Also, the toxicity of the Cry $3 \mathrm{~A} \delta$-endotoxin in $P$. vorax larvae was evaluated by engineering the specific residues D354, R345, Y350 and Y351 (loop I in the binding domain), and Q482, S484 and R485 (loop III) in domain II (Wu \& Dean 1996, Wu et al. 2000).

\section{MATERIALS AND METHODS}

Samples collection: Different colombian potato crops (Solanum tuberosum spp. andigena var. Diacol Capiro R-12) (Andean region) were sampled randomly chosen. They were located in Cerro La Conejera ecological park (Geographic coordinates $4^{\circ} 47^{\prime} 14,3^{\prime \prime}-5^{\circ} 35^{\prime} 13$ ' $\left.\mathrm{N}, 74^{\circ} 4^{\prime} 3,4^{\prime \prime}-73^{\circ} 15^{\prime} 49,7^{\prime \prime} \mathrm{W}\right)$ and Romeral municipal rural settlement of Sibate municipality (Geographic coordinates 4²6’3' N, $74^{\circ} 14^{\prime} 8$ " W). No commercial B. thuringiensis based product had been used in any of the sampled areas. Two hundred grams of samples (soil and stored products) was collected with a sterile spatula at $10 \mathrm{~cm}$ deep. Dead $P$. vorax insects were obtained from soil and tubers. Samples were stored in labeled sterile plastic bags at room temperature until processed.

Bacterial strains: $B$. thuringiensis subsp kurstaki (HD1), B. thuringiensis subsp aizawai (HD137), B. thuringiensis subsp. tenebrionis and $B$. thuringiensis subsp. san diego were supplied by Bacillus Genetic Stock Center (The Ohio State University, Columbus, OH). Acetate selection method developed by Travers et al. (1987) was used to isolate the native strains.

Phase contrast microscopy and SDSPAGE: Parasporal inclusions of each isolate were classified through phase contrast microscopy in one of the following types: bipyramidal, rectangular, cuboidal, spherical, triangular, and amorphous. Spore-crystal suspensions were used for protein analyses in 10\% SDSpolyacrylamide gels.

PCR cry gene analysis: Native $B$. thuringiensis strains were characterized in terms of cry gene presence. Those strains which reacted with the general cry primers were characterized subsequently through additional PCRs with specific primers, in order to identify cry $1 \mathrm{Aa}$, cry $1 \mathrm{Ab}$, cry $1 \mathrm{Ac}$, cry $1 \mathrm{Ba}$, cry $1 \mathrm{Da}$, cry 2 , and cry 3 and cry 7 genes presence. The Cry primers used were designed by Cerón et al. (1994, 1995) and Ben-Dov et al. (1997). DNA preparation and PCRs were made in a thermocycler (Perkins-Elmer model 480) using Cerón et al. (1995) methods.

Mutagenesis and protein isolation: Three Cry 3Aa-mutants have been described elsewhere $(\mathrm{Wu}$ et al. 2000, Wu \& Dean 1996) and were constructed by introduction of the mutations D354E (loop 1 in domain II), R345A, $\Delta \mathrm{Y} 350, \Delta \mathrm{Y} 351$ (loop 1 in domain II), Q482A, S484A and R485A (loop 3 in domain 
II) in expression plasmid pMH10 derived from pKK233-2 (Pharmacy LKB Biotechnology), using the Kit GeneTailor ${ }^{\text {TM }}$ Site-Directed Mutagenesis System (Invitrogen). After mutagenesis, single-strand DNA sequencing was carried out (Macrogen, Korea).

Wild-type cry $3 \mathrm{Aa}$ and mutant genes were expressed in Escherichia coli XL-1-Blue. Cells were grown for $48 \mathrm{~h}$ in $500 \mathrm{ml}$ of TB medium (Sambrook et al. 1989) containing $100 \mu \mathrm{g} /$ $\mathrm{ml}$ ampicillin. Crystal extracts were prepared and solubilized in $50 \mathrm{mM}$ sodium carbonate buffer ( $\mathrm{pH}$ 10.0). The concentration of solubilized protoxin was determined by Lowry assay (Lowry et al. 1951). When necessary, activation of protoxin was performed by adding trypsin at a ratio of 1:10 (trypsin:protoxin, $\mathrm{w} / \mathrm{v}$ ) and incubating for $2 \mathrm{~h}$ at $37^{\circ} \mathrm{C}$. The activated toxin was used immediately. Protoxin and toxins were analyzed by SDS-polyacrylamide gel (8\%) electrophoresis (SDS-PAGE).

Bioassays: The biopesticide activity of different $B$. thuringiensis strains, Cry $3 \mathrm{Aa}$ and mutants, was evaluated on first instar larvae of $P$. vorax from a laboratory colony. Potato cubes were surface contaminated with a toxin concentration of 10000 (bacterial strains) and 2000 (Wild-type cry 3Aa and mutants) $\mathrm{ng} / \mathrm{cm}^{2}$ diluted in $60 \mu \mathrm{l}$ deionized water. Cubes were distributed in plate wells and each one was infested with one $P$. vorax first instar larvae. Plates were sealed and incubated into a $18^{\circ} \mathrm{C}, 60 \pm 5 \%$ relative humidity, and $12: 12 \mathrm{~h}$ light:dark photoperiod room. In insect bioassay 72 neonate larvae per treatment were used and mortality was recorded after 7 days (Martínez \& Cerón 2002).

\section{RESULTS}

A total of 300 (42.85\%, out of 700) strains, of $P$. vorax environment samples examined showed colonial and microscopic morphology identical to $B$. thuringiensis. The value of Bt index, according to Iriarte et al. (1998), calculated as a number of $B$. thuringiensis isolates, divided by the total number of Bacillus strains, was assessed to be 0.43 . Phase contrast microscopy demonstrated that all strains presented diverse crystal morphologies: bipyramidal, cuboidal, point and pleomorphic. Isolates with bipyramidal and cuboidal-shape crystals predominated on the soil and dead insects $(63 \%$ and $25 \%$ respectively) (Fig. 1).

All B. thuringiensis isolates of their crystal protein products were further characterized by SDS-PAGE. The results revealed that the
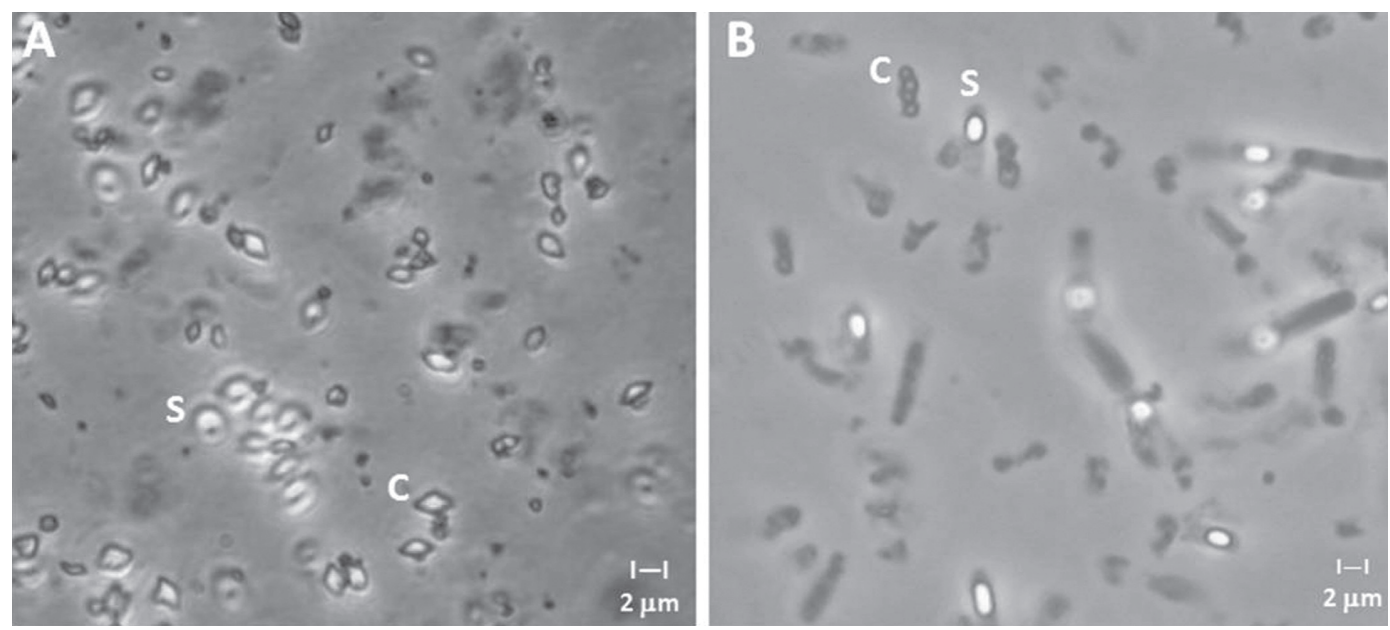

Fig. 1. Phase contrast micrograph of B. thuringiensis isolates showing the bipyramidal and cuboidal crystals. (A) Isolate IBUN27p, (B) Isolate IBUN72.1. (S) Spore, (C) Crystal. 
colombian $P$. vorax environment strains synthesize a protein, or group of proteins, with a molecular mass between 35 and $135 \mathrm{kDa}$ (Fig. 2 ). The highest percentage of isolates contained two protein types, 130 and $60 \mathrm{kDa}$; and, in addition to these proteins, an intermediate molecular weight protein of approximately 100 $\mathrm{kDa}$. However, insects isolates possessing others toxins (125, 40 and $35 \mathrm{kDa})$ combinations were represented by less than $2 \%$.

The profiles of all PCR products were compared with those of standard strains. An isolate was considered to contain a determined gene only when the amplification product was of the expected size. Analysis of the B. thuringiensis isolates indicated that most contained several cry 2 genes, as well as cry 1 (Table 1). Within the 300 strains, 212 isolates $(70.6 \%)$ harbored cry 1, cry 2, cry 3 or cry 7 gene. Several strains carried the cry 1-type genes (107 or $35.6 \%)$ or cry 2 gene (134 or $44.6 \%$ ) whereas only 51 strains $(17 \%)$ contained the cry 3-cry 7 genes (Table 1). Eighty-eight of the 300 isolates $(29.3 \%)$ did not harbor any of the cry 1 , cry 2 or cry 3- cry 7 genes. All of the different Cry 1 subfamilies were observed with different frequencies. Among them, cry $1 \mathrm{~A}$ in 95 strains $(31.6 \%)$ and cry $1 \mathrm{~B}$ in 50 strains $(16.6 \%)$ were considered abundant, while cry $1 \mathrm{D}$ in 39 strains (13\%) and cry 1C in 21 strains $(7 \%)$ were less prevalent (Table 1). The study of cry gene combinations in cry gene-containing isolates showed that more than 49\% (147) harbored more than one type of cry gene. About $74.7 \%$ of the cry 1 gene-containing isolates also harbored a cry 2 gene while $59.7 \%$ of the cry 2 gene-containing isolates also harbored a cry 1-type gene and about $5.5 \%$ of the cry 3- cry 7 gene-containing isolates also harbored cry 1 gene. However, only $2.8 \%$ of the cry 1 gene-containing isolates also harbored a cry 3cry 7 gene. These results indicated that cry 1 and cry 2 genes have a high tendency to occur together and the cry 3-cry 7 gene frequently occurred alone.

The expression of the cry $3 \mathrm{Aa}$ gene in XL1-Blue was analyzed by sequencing (data not shown) and SDS-PAGE (Fig. 3). The predominant band of expressed protein visualized on SDS-PAGE was $73 \mathrm{kDa}$. These crystal proteins could be further reduced to 67 and $55 \mathrm{kDa}$ if treated with trypsin (Fig. 3). All mutants were highly expressed as inclusion bodies in E. coli, similar to the wild type Cry 3Aa.

To test the toxicity of $B$. thuringiensis native strains, Cry $3 \mathrm{Aa}$ and mutants, first instar larvae of $P$. vorax were exposed to media whose surface was spread with $10000 \mathrm{ng} / \mathrm{cm}^{2}$ protoxins

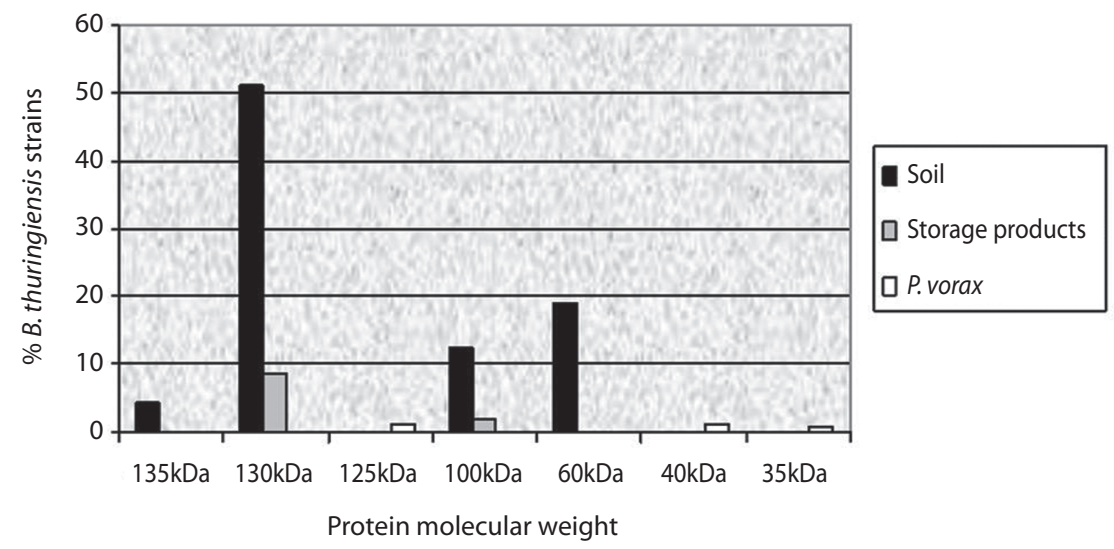

Fig. 2. Protein band patterns in B. thuringiensis strains from P. vorax ecosystem. (口) B. thuringiensis strains isolated from soil; ( $\square$ ) B. thuringiensis strains isolated from storage products; ( $\square$ ) B. thuringiensis strains isolated from dead insects. Polypeptides were visualized by Coomassie blue staining. 
TABLE 1

The cry gene combination profiles present in the B. thuringiensis strain collection from $\mathrm{P}$. vorax ecosystem $(n=300)$

\begin{tabular}{|c|c|c|c|}
\hline No. & cry gene profiles & No. of isolates & Freq. $(\%)$ \\
\hline 1 & cry 3, cry 7 & 51 & 17 \\
\hline 2 & cry $1 \mathrm{Aa}$, cry $1 \mathrm{Ab}$, cry $1 \mathrm{Ba}$, cry $1 \mathrm{Ca}$, cry $1 \mathrm{Da}$ & 5 & 1.6 \\
\hline 3 & cry $1 \mathrm{Aa}$, cry $1 \mathrm{Ab}$, cry $1 \mathrm{Ba}$, cry $1 \mathrm{Ca}$, cry $1 \mathrm{Da}$, cry 2 & 11 & 3.6 \\
\hline 4 & cry $1 \mathrm{Aa}$, cry $1 \mathrm{Ab}$, cry $1 \mathrm{Ba}$, cry $1 \mathrm{Ca}$, cry $1 \mathrm{Da}$, cry 3 , cry 7 & 1 & 0.3 \\
\hline 5 & cry $1 \mathrm{Aa}$, cry $1 \mathrm{Ba}$, cry $1 \mathrm{Ca}$, cry $1 \mathrm{Da}$ & 1 & 0.3 \\
\hline 6 & cry $1 \mathrm{Aa}$, cry $1 \mathrm{Ba}$, cry $1 \mathrm{Ca}$, cry $1 \mathrm{Da}$, cry 3 , cry 7 & 2 & 0.6 \\
\hline 7 & cry $1 \mathrm{Ba}$, cry $1 \mathrm{Ca}$, cry $1 \mathrm{Da}$ & 1 & 0.3 \\
\hline 8 & cry $1 \mathrm{Aa}$, cry $1 \mathrm{Ab}$, cry $1 \mathrm{Ac}$, cry 2 & 5 & 1.6 \\
\hline 9 & cry $1 \mathrm{Aa}$, cry $1 \mathrm{Ab}$, cry $1 \mathrm{Ac}$, cry $1 \mathrm{Ba}$, cry $1 \mathrm{Da}$ & 1 & 0.3 \\
\hline 10 & cry $1 \mathrm{Aa}$, cry $1 \mathrm{Ab}$, cry $1 \mathrm{Ac}$, cry $1 \mathrm{Ba}$, cry $1 \mathrm{Da}$, cry 2 & 17 & 5.6 \\
\hline 11 & cry $1 \mathrm{Aa}$, cry $1 \mathrm{Ab}$, cry $1 \mathrm{Ac}$ & 4 & 1.3 \\
\hline 12 & cry $1 \mathrm{Aa}$, cry $1 \mathrm{Ac}$, cry 2 & 8 & 2.6 \\
\hline 13 & cry $1 \mathrm{Aa}$, cry 2 & 2 & 0.6 \\
\hline 14 & cry $1 \mathrm{Ab}$, cry $1 \mathrm{Ac}$, cry 2 & 8 & 2.6 \\
\hline 15 & cry $1 \mathrm{Aa}$, cry $1 \mathrm{Ab}$ & 1 & 0.3 \\
\hline 16 & cry $1 \mathrm{Aa}$, cry $1 \mathrm{Ab}$, cry 2 & 2 & 0.6 \\
\hline 17 & cry $1 \mathrm{Ab}$ & 2 & 0.6 \\
\hline 18 & cry $1 \mathrm{Ab}$, cry 2 & 25 & 8.3 \\
\hline 19 & cry $1 \mathrm{Ba}$ & 9 & 3 \\
\hline 20 & cry $1 \mathrm{Ba}$, cry 2 & 2 & 0.6 \\
\hline 21 & cry 2 & 54 & 18 \\
\hline 22 & NA & 88 & 29.3 \\
\hline
\end{tabular}

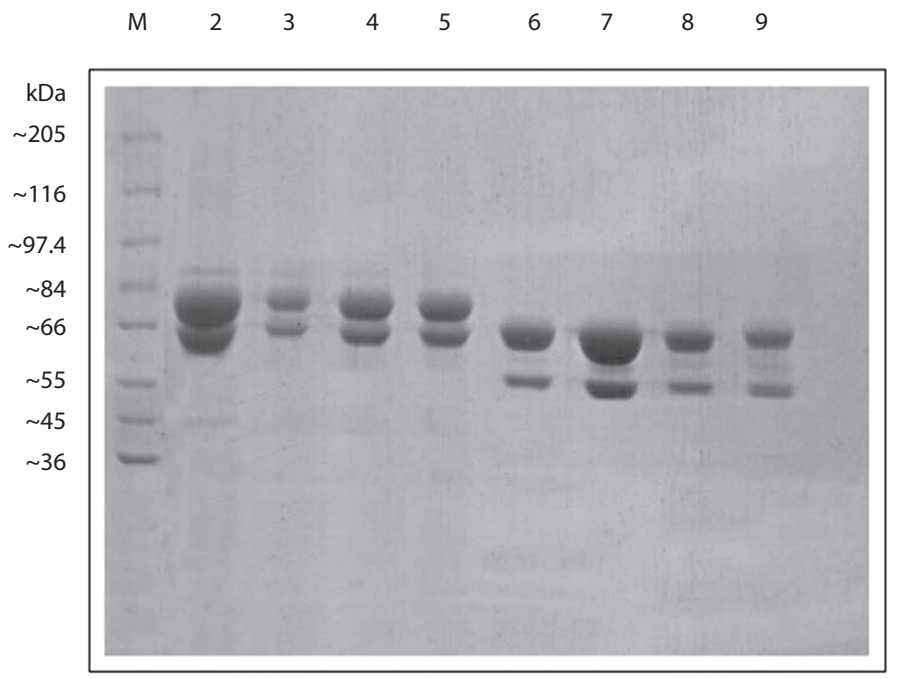

Fig. 3. Coomassie blue stained $12.5 \%$ SDS-PAGE comparing the expression of Cry3Aa proteins and trypsin digested toxins. Lanes: (1) Molecular weight marker (M); (2) wild-type Cry3Aa purified from E. coli; (3) loop 3 triple mutant (Q482A, S484A, R485A); (4) loop 1 triple mutant (R345A, $\Delta \mathrm{Y} 350, \Delta \mathrm{Y} 351$ ); (5) loop 1 mutant (D354E); (6) loop 3 triple mutant treated with trypsin; (7) wild-type Cry3Aa treated with trypsin; (8) loop 1 mutant treated with trypsin; (9) loop 1 triple mutant treated with trypsin. Each lane contained $12 \mu \mathrm{g}$ of protein. 
TABLE 2

Classification of the B. thuringiensis isolates in groups according to their toxicity levels against $\mathrm{P} . \operatorname{vorax}\left(10000 \mathrm{ng} / \mathrm{cm}^{2}\right)$

$\begin{array}{lccc}\text { Sample habitat } & \begin{array}{c}\text { Number of isolates causing } \\ \text { a mortality of } 0-10 \% \text { (three assays) }\end{array} & \begin{array}{c}\text { Number of isolates causing } \\ \text { a mortality of } 10-20 \% \text { (three assays) }\end{array} & \begin{array}{c}\text { Total isolates } \\ \text { examined }\end{array} \\ \text { Soil } & 224 & 17 & 241 \\ \text { Storage products } & 36 & 11 & 47 \\ \text { Dead insects } & 12 & 0 & 12 \\ \text { Total } & 272 & 28 & 300\end{array}$

TABLE 3

Toxicity against $\mathrm{P}$. vorax of Cry $3 \mathrm{Aa}$ wild type and mutants proteins $\left(2000 \mathrm{ng} / \mathrm{cm}^{2}\right)$

\begin{tabular}{|c|c|c|c|c|c|c|c|c|}
\hline \multirow{2}{*}{$\begin{array}{l}\text { Proteins } \\
\text { Cry3Aa wild type }\end{array}$} & \multicolumn{3}{|c|}{$\begin{array}{c}\text { Mortality (\%) with } \\
\text { protoxin (three assays) }\end{array}$} & \multicolumn{3}{|c|}{$\begin{array}{l}\text { Mortality (\%) with toxin } \\
\quad \text { (three assays) }\end{array}$} & \multirow{2}{*}{ 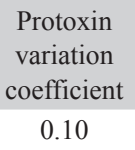 } & \multirow{2}{*}{$\begin{array}{c}\begin{array}{c}\text { Toxin } \\
\text { variation } \\
\text { coefficient }\end{array} \\
0\end{array}$} \\
\hline & 12.9 & 15.62 & 15.62 & 9.37 & 9.37 & 9.37 & & \\
\hline $\mathrm{R} 345 \mathrm{~A}, \Delta \mathrm{Y} 350, \Delta \mathrm{Y} 351$ & 6.25 & 9.37 & 9.37 & 15.62 & 21.87 & 21.87 & 0.21 & 0.18 \\
\hline Q482A, S484A, R485A & 9.37 & 6.25 & 9.37 & 9.37 & 12.5 & 9.37 & 0.21 & 0.17 \\
\hline D354E & 6.25 & 6.25 & 9.37 & 15.62 & 15.62 & 12.5 & 0.2 & 0.12 \\
\hline
\end{tabular}

and activated toxins, and $2000 \mathrm{ng} / \mathrm{cm}^{2}$ recombinant protoxins and toxins. Larvae exposed to toxin treated media exhibited a mortality percentage lower than 22\% (Tables 2 and 3 ).

\section{DISCUSSION}

Since potatoes are the most important crop in the Andean region, all the samples collected were related to this crop, and $100 \%$ of them had an origin associated with the important pest in the area: the Andean weevil P. vorax. Here, we determined the presence of different cry genes within the $P$. vorax ecosystem collection. The selection of $B$. thuringiensis isolates was based principally on phase-contrast microscopy. The Bt index was high (0.43). Probably, humidity and excrements produced by $P$. vorax larvae in the galleries of the infested potatoes make a favorable environment for $B$. thuringiensis colonization. Similar to the lepidopteran-active reference strains (especially B. thuringiensis kurstaki), most of the isolates exhibited two major polypeptides with a relative molecular mass in the range of 130 to $140 \mathrm{kDa}$ and approximately $70 \mathrm{kDa}$, respectively. The SDS-PAGE analysis showed other proteins $(125,100,40$ and $35 \mathrm{kDa}$ from soil, store products and dead $P$. vorax samples) in $B$. thuringiensis strains, thus, these results predicted that our insect isolates contain possible novel Coleopteran-specific proteins. Based on the varied parasporal polypeptide patterns of the isolates, we conclude that this $B$. thuringiensis collection has quite an attractive diversity of Cry proteins.

The important biological activity of $B$. thuringiensis isolates appears to be derived from the combined attributes of different Cry toxins formed into a proteinaceous body. Determination of their Cry gene contents is useful for the prediction of their toxicity. B. thuringiensis strains recovered from $P$. vorax environment were diverse in terms of their cry gene contents. According to PCR analysis, the cry 1, cry 2 and cry 3-cry 7 genes were observed in our B. thuringiensis collection but in different frequency. The cry 2 genes were the most 
frequently found in the native isolates collection (Table 1). A high frequency of cry 1 genes seems to be common to all $B$. thuringiensis strain collections analyzed so far (Bravo et al. 1998, Hernández et al. 2005, Cinar et al. 2008). It is possible that cry 1 gene-containing strains may be more abundant. We cannot exclude the probability that the high percentage of $c r y$ 2 genes in $B$. thuringiensis isolates may have been biased because of the procedure used for selection (Bravo et al. 1998). The second most abundant genes in the bacterial strain collection were the cry 1 genes and then the cry 3- cry 7 genes (Table 1). In our study, the cry 2 gene $(44.6 \%)$ was detected more frequently than in other reports. For instant Ben-Dov et al. (1997) found that strains containing cry 1 genes were the most abundant; Bravo et al. (1998) detected $49.5 \%$ of cry 1 gene; Uribe et al. (2003) reported $73 \%$ of cry 1 gene; Wang et al. (2003) detected $76.5 \%$ of cry 1 gene and $70 \%$ of cry 2 gene; Thammasittirong \& Attathom (2008) reported strains containing cry 1-type genes $(81.3 \%)$ at the same frequency as strains harboring cry 2 gene $(80.6 \%)$. There is low presence of cry 3-cry 7 gene in potato crops infested with $P$. vorax. It is important to mention that many of the isolates harbored more than one cry gene, suggesting that B. thuringiensis strains have a high frequency of genetic information exchange. Twenty-one distinct cry gene profiles were identified in our collection (Table 1), which indicates the high diversity in the cry gene contents of the $B$. thuringiensis strains. The analysis of the genes showed that the cry 1 and cry 2 genes were most often present together and most of the bacterial strains contained more than one type of lepidopteran-active cry gene. Some strains containing combinations of cry genes that were less frequently observed, such as lepidopteranactive cry 1 genes and coleopteran-active cry 3- cry 7 genes, were identified (Table 1), these isolates are good possibilities in the search for biological control agents with a wider spectrum of activity. Other groups have reported the presence of cry 1 genes and cry 3-cry 7 genes in the same B. thuringiensis strain (Bravo et al.
1998), suggesting that strains with dual activity are also present in other regions. The great variability and distribution of cry gene content in $B$. thuringiensis strains even from the same country is well recognized, and the variations were likely associated with differences in the biological, geographical and ecological properties of the collected areas. The above evidences show the importance of establishing collections of this microorganism in different countries for developing strategies of biological insect control. Finally, 88 isolates did not react with any PCR primer. These isolates are candidates for harboring putative different cry genes. The identification of different $B$. thuringiensis isolates could be the first phase in the project for finding major toxicities, since different proteins may be toxic for new insects. The characterization of different cry genes should be encouraged once the susceptible insect is identified and more evidence on the potential of different proteins as pest control agents is available.

Under the conditions tested both native strain and recombinant and mutant cry $3 \mathrm{Aa}$ proteins presented in bioassays a mortality below $22 \%$ with the evaluated dose (Tables 2 and 3). The original objective of this project was to select strains, or recombinant proteins, with activity against $P$. vorax. Unfortunately, none of the isolates, or wild type Cry $3 \mathrm{Aa}$ and mutants, was toxic against this weevil. In spite of the fact that cry3 proteins bind to $P$. vorax brush border membrane vesicles (Martinez \& Cerón 2004) it is still difficult to find active proteins to this pest. This result is not at all unexpected, as most screening studies of susceptibility to $B$. thuringiensis proteins have shown a frequent insecticidal toxicity of this organism to lepidopteran species, while only very few isolates and toxins have been found active against Coleoptera (Hernandez et al. 2005). Also, we tested the theory that surface loops in domain II of Cry $3 \mathrm{Aa}$ are involved in receptor binding of $P$. vorax larvae. Previous results revealed that substitutions within surface exposed loops of domain II on the cry $3 \mathrm{Aa}$ can affect reversible and irreversible receptor binding in coleopteran (Wu \& Dean 1996, Wu 
et al. 2000). However, none of the mutants was toxic to $P$. vorax larvae. The implications of our studies are important for new design of $\delta$-endotoxins that overcome insect resistance to these toxins and for altered or improved insecticidal activity, as has been achieved in other Cry proteins.

\section{RESUMEN}

El gorgojo andino Premnotrypes vorax es una causa importante de daño en los cultivos colombianos de este tubérculo. Debido al impacto que esta plaga tiene sobre la economía del país, nos interesamos en buscar alternativas nuevas para el control biológico de $P$. vorax, basadas en la bacteria entomopatógena Bacillus thuringiensis. Se recolectaron un total de 300 cepas de $B$. thuringiensis a partir de plantaciones de papa infestadas con $P$. vorax, las cuales fueron analizadas por medio de la morfología del cristal, SDS-PAGE, PCR y ensayos biológicos. La mayoría de los aislamientos de B. thuringiensis presentaron cristales bipiramidales. Los análisis de SDS-PAGE indicaron la presencia de siete grupos de cepas con $\delta$-endotoxinas que variaban entre 35 a $135 \mathrm{kDa}$. Las pruebas con PCR demostraron que los genes cry 2 y cry 1 fueron significativamente más frecuentes en el medioambiente de $P$. vorax. Además, se utilizó la mutagénesis sitio-dirigida para modificar la proteína Cry3Aa. Se analizaron tres toxinas mutantes, 1 (D354E), 2 (R345A, $\Delta$ Y350, $\Delta$ Y351), y 3 (Q482A, S484A, R485A), para determinar su actividad contra larvas de $P$. vorax. Los ensayos de toxicidad señalaron escasa, o nula, actividad hacia $P$. vorax tanto para las cepas, la toxina Cry3Aa de referencia y las proteínas Cry3Aa mutantes. La caracterización genética de la colección puede proveer oportunidades para la selección de cepas que pueden evaluarse por medio de bioensayos contra otros insectos-plaga de importancia agrícola, y para el diseño de proteínas Cry con actividad toxica mejorada.

Palabras clave: cepa nativa, gorgojo andino, proteína Cry3Aa, cultivo de papa, mutagénesis sitio-dirigida.

\section{REFERENCES}

Arrieta, G. \& A.M. Espinoza. 2006. Characterization of a Bacillus thuringiensis strain collection isolated from diverse Costa Rican natural ecosystems. Rev. Biol. Trop. 54: 13-27.

Ben-Dov, E., A. Zaritsky, E. Dahan, Z. Barak, R. Sinai, R. Manasherob, A. Khamraev, E. Troitskaya, A. Dubitsky, N. Berezina \& Y. Margalith. 1997. Extended screening by PCR for seven cry group genes from field-collected strains of Bacillus thuringiensis. Appl. Environ. Microbiol. 63: 4883-4890.
Bravo A., S. Sarabia, L. Lopez, H. Ontiveros, C. Abarca, A. Ortiz, M. Ortiz, L. Lina, F. Villalobos, G. Peña, M.E. Nuñez-Valdez, M. Soberón \& R. Quintero. 1998. Characterization of cry genes in a mexican Bacillus thuringiensis strain collection. Appl. Environ. Microbiol. 64: 4965-4972.

Cerón, J., L. Covarrubias, R. Quintero, A. Ortiz, M. Ortiz, E. Aranda \& A. Bravo. 1994. PCR analysis of the CryI insecticidal crystal family genes from Bacillus thuringiensis. Appl. Environ. Microbiol. 60: 353356.

Cerón, J., A. Ortiz, R. Quintero, L. Guereca \& A. Bravo. 1995. Specific PCR primers directed to identify cry I and cry III genes within a Bacillus thuringiensis strain collection. Appl. Environ. Microbiol. 61: 38263831 .

Cinar, C., O. Apaydin, A.F. Yenidunya, S. Harsa \& H. Gunes. 2008. Isolation and characterization of Bacillus thuringiensis strains from olive-related habitats in Turkey. J. Appl. Microbiol. 104: 515-525.

Hernández, S., R. Andrew, Y. Bela \& J. Ferré. 2005. Isolation and toxicity of Bacillus thuringiensis from potato-growing areas in Bolivia Carmen. J. Invertebr. Pathol. 88: 8-16.

Herrera, F. 1997. El gusano blanco de la papa: biología, comportamiento y prácticas de manejo integrado. Ministerio de Agricultura y Desarrollo Rural/Corporación Colombiana de Investigación Agropecuaria CORPOICA Regional Uno Cundinamarca-Boyacá. (Available on-line: http://www.redepapa.org/patologiared.html).

Iriarte, J., Y. Bel, M.D. Ferrandis, R. Andrew, J. Murillo, J. Ferre \& P. Caballero. 1998. Environmental distribution and diversity of Bacillus thuringiensis in Spain. Syst. Appl. Microbiol. 21: 97-106.

Kati, H., K. Sezen, R. Nalcacioglu \& Z. Demirbag. 2007. A highly pathogenic strain of Bacillus thuringiensis serovar kurstaki in lepidopteran pests. J. Microbiol. 45: 553-557.

López-Pazos, S.A. \& J. Cerón. 2007. Three-dimensional structure of Bacillus thuringiensis toxins: a review. Acta Biol. Colomb. 12: 19-32.

Lowry, O., N.J. Rosenbrough, A.L. Farr \& R.J. Randall. 1951. Protein measurement with the Folin phenol reagent. J. Biol. Chem. 193: 265-275.

Mahalakshmi, A., R. Shenbagarathai \& K. Sujatha. 2005. Identification of novel indigenous Bacillus thuringiensis isolates. Indian J. Exp. Biol. 43: 867-872. 
Martínez, W. \& J. Cerón. 2004. Unión de proteínas de Bacillus thuringiensis con vesículas de las microvellosidades del tracto digestivo del gusano blanco de la papa Premnotrypes vorax (Coleoptera: Curculionidae). Rev. Colomb. Entomol. 30: 51-56.

Sambrook, J., E.F. Fritsch \& T. Maniatis. 1989. Molecular cloning: a laboratory manual. Cold-Spring Harbor Laboratory, Cold Spring Harbor, New York, USA.

Schnepf, E., N. Crickmore, J. Van Rie, D. Lereclus, J. Baum, J. Feitelson, D.R. Zeigler \& D.H. Dean. 1998. Bacillus thuringiensis and its pesticidal crystal proteins. Microbiol. Mol. Biol. Rev. 62: 775-806.

Song, L., M. Gao, S. Dai, Y. Wu, D. Yi \& R. Li. 2008. Specific activity of a Bacillus thuringiensis strain against Locusta migratoria manilensis. J. Invertebr. Pathol. 98: 169-176.

Thammasittirong, A. \& T. Attathom. 2008. PCR-based method for the detection of Cry genes in local isolates of Bacillus thuringiensis from Thailand. J. Invertebr. Pathol. 98: 121-126.

Travers, R.S., P.A. Martin \& C.F. Reichelderfer. 1987. Selective process for efficient isolation of soil $\mathrm{Baci}$ llus spp. Appl. Environ. Microbiol. 53: 1263-1266.
Uribe, D., W. Martínez \& J. Cerón. 2003. Distribution and diversity of cry genes in native strains of Bacillus thuringiensis obtained from different ecosystems from Colombia. J. Invertebr. Pathol. 82: 119-127.

Wang, J.H., A. Boets, J. Van Rie \& G.X. Ren. 2003. Characterization of cry 1 , cry 2 and cry 9 genes in $\mathrm{Baci}$ llus thuringiensis isolates from China. J. Invertebr. Pathol. 82: 63-71.

Wu, S.J. \& D. Dean. 1996. Functional significance of loops in the receptor binding domain of Bacillus thuringiensis cry IIIA $\delta$-Endotoxin. J. Mol. Biol. 255: 628-640.

Wu, S.J., C. Koller, D. Miller, L. Bauer \& D. Dean. 2000. Enhanced toxicity of Bacillus thuringiensis Cry3A $\delta$-endotoxin in coleopterans by mutagenesis in a receptor binding loop. FEBS Letters 473: 227-232.

\section{INTERNET REFERENCE}

Crickmore, N., D.R. Zeigler, E. Schnepf, J. Van Rie, D. Lereclus, J. Baum, A. Bravo \& D.H. Dean. 2008. Bacillus thuringiensis toxin nomenclature. (Downloaded: February 2008. http://www.lifesci.sussex. ac.uk/Home/Neil_Crickmore/Bt/) 
